\title{
Remembering Richard Lugar
}

\author{
PAUL HELMKE
}

\begin{abstract}
Paul Helmke, former three-term mayor of Fort Wayne, Indiana, offers his memories of Indiana Senator Richard G. Lugar, who died April 28, 2019. Helmke met Lugar in 1969, while the latter was serving as mayor of Indianapolis and planning Unigov, the consolidation of the city with surrounding townships in Marion County. Helmke discusses how Lugar's career inspired his own career at both the state and national levels.

KEYWORDS: Paul Helmke, Richard G. Lugar, Indianapolis, Fort Wayne, Unigov, Republican Party, Indiana politics, National League of Cities, U. S. Conference of Mayors, United States Senate, political campaigns
\end{abstract}

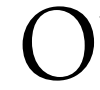

utside of my family, the greatest direct personal influence on my career in politics and public service was Richard G. Lugar. He served as a role model and an example of how elected officials could help make things better at the local, national, and international levels.

My first direct engagement with Lugar came on February 1, 1969, when I served on a panel in my hometown, Fort Wayne, responding to his remarks about "Citizens' Stake in Local Government." I was then the student body vice-president at Indiana University, Bloomington; the other student on the panel was my high school friend, Graham Richard, who was attending Princeton. I remember being very impressed by the new mayor of Indianapolis. (He must have inspired the two of us about the importance of local government, because we each went on to serve as mayors of Fort

Paul Helmke is Professor of Practice at the O'Neill School of Public and Environmental Affairs, Indiana University, Bloomington. He is the former president and CEO of the Brady Center/ Brady Campaign to Prevent Gun Violence, and former three-term mayor of Fort Wayne, Indiana.

INDIANA MAGAZINE OF HISTORY, 115 (December 2019). @ 2019, Trustees of Indiana University. doi: 10.2979/indimagahist.115.4.03 
Wayne-me, from 1988 to 2000, and Graham, from 2000 to 2008.) Mayor Lugar subsequently invited me to intern with him during the upcoming summer. I was working in Bloomington, where my new role as student body president kept me busy, so I turned down the offer. I later learned that one of the people who took that internship was another Princeton student who ended up with a pretty good political career of his own, Mitch Daniels.

A major priority for Lugar in 1968-69 was his plan to consolidate governmental services in Indianapolis and Marion County. His political skills led to the Indiana Legislature approving the creation of Unigov, effective January 1, 1970. This feat helped form the foundation for the growth and success of Indiana's capital city during the following decades.

When I returned to Fort Wayne, Indiana's second largest city, after graduating from law school, I joined a group called Fort Wayne Future, one of whose goals was modernizing our area's local governmental structure. Following Lugar's example, I started pushing for a consolidation of local governmental services, with some modifications from the Unigov model to reflect both the urban-rural split in Allen County and some lessons already learned from the Indianapolis experience. My inability to move this issue along with an outside-of-government citizen group was one of the reasons I decided to run for mayor of Fort Wayne in 1987-I wanted to push the issue from the inside. Even as mayor, however, my proposals for a consolidated urban-county government were unsuccessful-Unigov was not necessarily popular in the rest of the state-but I was able to accomplish my fallback plan to annex as much of the adjacent urban areas as possible. As a result, Fort Wayne's population grew from approximately 170,000 when I took office to over 260,000 today. One of the things that kept me pushing for such reform-over serious, continued political and legal opposition-was the inspiration that I had received from Mayor Lugar's accomplishments in his hometown.

As mayor, I also tried to follow some of what Lugar was able to do by working with other mayors at the national level. He was elected president of the National League of Cities (NLC) with a victory over New York City mayor John Lindsay, and later became known as President Nixon's "favorite mayor." Despite the negatives that later became associated with this nickname, Lugar's urban leadership positions during the Nixon presidency heralded an era that saw the initiation or expansion of Community Development Action Grants, revenue sharing, Urban Development Action Grants, and other federal programs for the cities. Lugar's example led me to become president of the U. S. Conference of Mayors. Working closely 


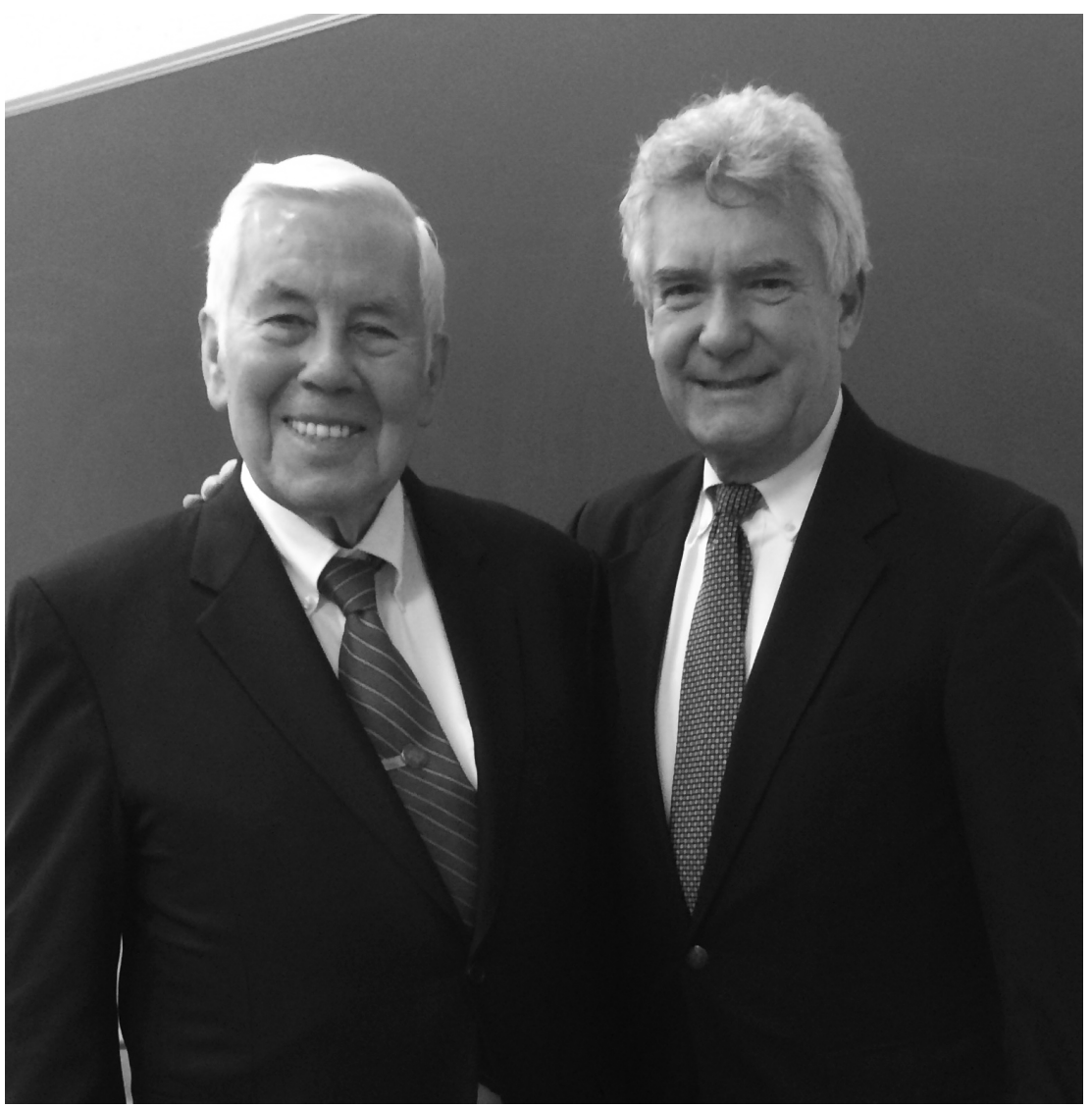

Senator Richard G. Lugar and Paul Helmke.

Courtesy of the author

with the Clinton administration carried some political risks for me, but I felt that supporting a "stimulus package" for cities (which Congress blocked), background checks for gun purchasers, and programs supporting community policing and domestic violence initiatives was the right thing to do for my city. When contacted, Lugar and his staff were responsive, and often supportive, to these issues as well.

Politically, Lugar showed me the importance of pushing forward, even after a defeat. I saw him frequently in 1974, when he was running for U. S. Senate against Birch Bayh, and my father, Walter P. Helmke, was running for U. S. Congress against Democrat J. Edward Roush. The Watergate scandal, and Nixon's resignation and subsequent pardon, made this a very 
bad year for Republicans. Rather than let his loss discourage him, Lugar came back two years later to defeat Vance Hartke for U. S. Senate. Once my father decided not to run again, I became active in other campaigns and ran for an open congressional seat in 1980. I was discouraged by my loss in the primary to Dan Coats (who had taken the job as Dan Quayle's district director that I had turned down two years earlier), but I stayed active in the party, campaigned for Lugar (even standing in for him at a debate with his opponent) when he ran for reelection in 1982, and with his encouragement got back into the arena when I was asked to run for mayor in 1987. Even with later disappointments (as a potential vice-presidential pick in 1988, in a short-lived consideration of a presidential run in 1996, and in his failed Senate primary of 2012), Lugar's continued dignity and service set a positive example for me and others.

Lugar was also important to me and my family in another way-my younger brother, Mark Helmke, left his job as a reporter for the Fort Wayne News-Sentinel to work as Lugar's press secretary in the early 1980scontinuing, off and on, in various roles, through the 2012 primary. The office had a reputation as one of the best places to work or intern on the Hill. Every Lugar staffer that I ever knew ended up staying close to the Senator throughout his lifetime.

One of the things I admired most about Senator Lugar was his belief that his constituents wanted to hear the straight, in-depth story of what was happening in Washington, D. C., and the world. I'd hear him at Lincoln Day dinners and other events talk for an hour, without notes, on the intricacies of the latest budget battle, the importance of securing the nuclear weapons in the former Soviet Union, or the complexities of the situation in the Middle East. He never talked down to the voters or relied on simple "bumper sticker" slogans. After he left office, I heard him speak similarly to many groups, including my students, on the IU Bloomington campus, as well as in D. C. He remained a thoughtful advocate for the positive things that our governmental and political system could do to make the world, and our country, a better place.

The last time I was with Senator Lugar-on March 22, 2019, just a few weeks before his death-we talked as he viewed his papers on display at IU's Lilly Library. In our conversation, as well as in his remarks to the group at the opening reception, he recalled some of the personal highlights of his life and his appreciation for all the opportunities our state had given him. Our country, and the world, needs more people like Richard Lugar. 